\title{
Increase in hawksbill sea turtle Eretmochelys imbricata nesting in Barbados, West Indies
}

\author{
Jennifer A. Beggs ${ }^{1,2, *}$, Julia A. Horrocks ${ }^{1}$, Barry H. Krueger ${ }^{1}$ \\ ${ }^{1}$ Department of Biological and Chemical Sciences, University of the West Indies, Cave Hill Campus, Barbados BB11000, \\ West Indies \\ ${ }^{2}$ Present address: Mote Marine Laboratory, 1600 Ken Thompson Parkway, Sarasota, Florida 34326, USA
}

\begin{abstract}
Nesting by hawksbill sea turtles Eretmochelys imbricata in Barbados, West Indies, has been monitored since 1992. Data from the index beach indicate that the number of nests may have increased as much as 8-fold over this period. The estimated abundance of nesting females on Barbados is 1250, suggesting that this eastern Caribbean island now hosts one of the largest rookeries in the wider Caribbean, with over 230 females nesting on the index beach alone. Given its extreme easterly position and the prevailing north-westerly current flow into the Caribbean Sea, Barbados is likely to be a significant contributor to foraging grounds throughout the region. Primary females, which are untagged and without tag scars, made up the majority of females encountered on nesting beaches in most years, suggesting that reductions in juvenile and sub-adult mortality, both nationally and regionally, are significant to the increase in number of nesting females. Females nest every $2.47 \mathrm{yr}$ on average, although remigration intervals of individual females vary (range: 1 to $6 \mathrm{yr}$ ), suggesting environmental influences on nesting periodicity. The average clutch frequency estimated from the index beach was 4.1 nests per female, but that calculated from less intensively surveyed beaches was lower. Primary and Remigrant females differed in length, mass and clutch frequency; the results must be viewed with caution, however, as preliminary laparoscopic examinations revealed that some Primary females were not in fact nesting for their first season, and because differences in nest site fidelity between the 2 groups of females could potentially cause the differences in clutch frequencies estimated.
\end{abstract}

KEY WORDS: Eretmochelys imbricata $\cdot$ Abundance $\cdot$ Remigration $\cdot$ Clutch frequency $\cdot$ Index beach monitoring

Resale or republication not permitted without written consent of the publisher

\section{INTRODUCTION}

In 1973, the hawksbill sea turtle Eretmochelys imbricata was listed in Appendix I by the Convention on International Trade in Endangered Species of Wild Fauna and Flora (CITES), to protect it from the international trade that had contributed so significantly to its decline in the preceding decades. The continued global decline in hawksbill populations led to the species being listed as critically endangered on the IUCN Red List of Threatened Animals in the mid-1990s (Baillie \& Groombridge 1996), with Meylan (1999) estimating that a maximum of 5000 hawksbills nested annually in the Caribbean region (excluding Guyana, French Guiana, Suriname and Brazil).
Early historical accounts from the 1600s suggest that hawksbill sea turtles may have been less common around Barbados than around other islands of the eastern Caribbean (see Horrocks 1992). Evidently, by the turn of the 20th century, over-exploitation for meat and eggs came to be viewed as a significant threat to the sea turtle fishery around Barbados, and the first legislation to control turtle harvests was passed in 1904 . The netting of hawksbills by 50 to 60 fishermen between March and July each year was reported during the 1940s, and markets for shell in England were actively sought (letter written by D. Wiles, Fisheries Officer, 1948), suggesting that numbers of hawksbills were relatively plentiful in nearshore waters around the island in the middle of the last century. However by 
the 1980s, sea turtles nested rarely in Barbados (J. A. Horrocks pers. obs.), and the paucity was such that Witzell's (1983) global overview of hawksbills did not mention Barbados as a nesting location for the species.

The Barbados Sea Turtle Project (BSTP), based at the University of the West Indies, was initiated in 1987 to spearhead efforts to conserve dwindling sea turtle populations. Through research conducted by the BSTP, coral reefs in Barbados were shown to provide critical habitat for 2 distinct life phases of the hawksbill sea turtle: aggregations of juveniles which resided year round, and adults, many of which migrated from their foraging sites throughout the Caribbean to Barbados in order to breed (Horrocks et al. 2001, Krueger et al. 2006). The early focus of the BSTP was to gather quantitative information on the status of hawksbills around Barbados, and an index beach monitoring programme to assess the number of nesting females was initiated in 1992. An indefinite national moratorium on the capture of sea turtles was implemented in July 1998.

Systematic early morning counts of nests over a period of years can produce a trend in relative abundance (Schroeder \& Murphy 1999). However, since hawksbills rarely nest each year, annual nest counts are not useful in estimating abundance of sea turtles, unless paired with accurate estimations of average clutch frequency and remigration intervals. Clutch frequency and remigration data can only be collected during nighttime patrols, when individual nesting females can be tagged and identified. Existing clutch frequency estimates vary widely in the Caribbean (e.g. Garduño-Andrade et al. 1999, Richardson et al. 1999) and estimates of female abundance from nest counts are very sensitive to this parameter. If average clutch frequency increases with age of females (Frazer 1984, Bjorndal \& Carr 1989, Mortimer \& Bresson 1999) or if populations differ in the ratio of younger newly recruiting turtles to older remigrants, as a result of different patterns of mortality, these factors may complicate the use of average clutch frequency in estimates of abundance from different populations.

The primary objectives of the present study are to report the trend in numbers of hawksbill nests on Barbados since 1992, and to estimate the current size of the hawksbill rookery based on the reproductive parameters ascertained for the Barbados breeding population. Rookery size is not only important for assessment of the effects of conservation efforts nationally in Barbados, and for hawksbill status in the Caribbean region as whole, but also to allow meaningful interpretation of data currently being collected in genetic studies of the rookery origins of animals sampled on their foraging grounds (Bass et al. 1996, Bowen et al. 2007). Finally, since survey effort varies between different nesting beaches on Barbados, it has provided an opportunity for the impact of survey effort on estimations of clutch frequency to be assessed.

\section{MATERIALS AND METHODS}

Study area. Barbados is the easternmost island in the West Indian archipelago. It is approximately $32 \mathrm{~km}$ long and $23 \mathrm{~km}$ across at its widest point. The leeward west and southwest coast beaches are characterised by calm, low wave energy water conditions and narrow sloping beaches, and the windward coast with high wave energy and wide beaches. The most significant hawksbill nesting occurs on the $1.5 \mathrm{~km}$ index beach (Needham's Point, $13^{\circ} 04^{\prime} 41.33^{\prime \prime} \mathrm{N}, 59^{\circ} 36^{\prime} 32.69^{\prime \prime} \mathrm{W}$; Horrocks 1992; Fig. 1). Additional high-density nesting beaches occur along the west coast between Speightstown to the north and Fitts Village to the south, and along the south coast between Rockley and Dover (Fig. 1).

Survey effort. Between 1987 and 1997, data on hawksbill nesting were derived from 2 sources. The first source was public reports of nesting activities islandwide, through calls made to a $24 \mathrm{~h}$ operated cell

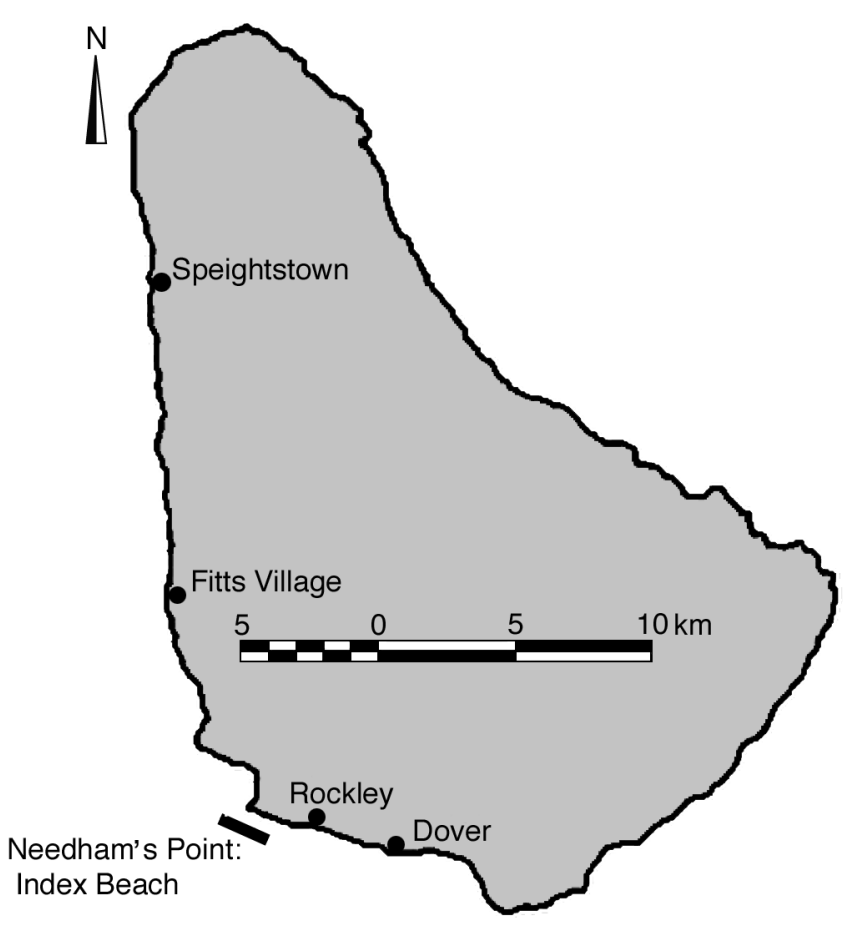

Fig. 1. Map of Barbados showing the Needham's Point index beach and high-density nesting beach stretches which run almost continuously between Speightstown and Fitts Village on the west coast and between Rockley and Dover on the southwest coast 
phone (the Sea Turtle Hotline). This method allowed data to be gathered from beaches islandwide and year round, but was biased against more isolated beaches. The second source of information was from yearround, early morning surveys (06:00 to 08:00 h) of the index beach for nests, which began in 1992.

In 1997, survey effort was increased in 2 ways. Firstly, the index beach was monitored throughout the night (20:00 to 04:00 h) between June 1 and September 30 each year, and secondly, 16 additional active nesting beaches (referred to as high density beaches) were surveyed, either once or twice during the night between 20:00 and 04:00 $\mathrm{h}$ or in the early morning, over the peak months of the nesting season (June 1 to September 30 ). These additional high-density nesting beaches were identified from early morning surveys and public reports.

The index beach was patrolled at hourly intervals throughout the night, allowing an opportunity to potentially witness all nesting activities (it took approximately 20 min to walk the length of the beach, and hawksbills typically require 1 to $1.5 \mathrm{~h}$ to nest). The objective was to identify all females that used the index beach over the monitoring period, and to record all nests made by each female. While every effort to witness all nesting activities was made, turtles were occasionally missed. This was because the threat of poaching of nesting females still occurred on Barbados, and protection of nesting females occasionally required observers to remain with a turtle until she left the beach, which sometimes resulted in other turtles being missed. Similarly, when several turtles emerged simultaneously, one may have been missed while data were collected from the other turtles. Females also occasionally nested outside of patrol hours (before 20:00 h or after 04:00 h) and were therefore not individually identified, but the tracks could always be identified to species.

The high-density nesting beach stretches were surveyed once or twice during the night, or in the early morning. These beaches were patrolled primarily to reduce the incidence of poaching and to mitigate against threats to nesting females and eggs as a result of extensive coastal development (e.g. artificial lights causing disorientation, coastal armouring resulting in falls and entrapment, narrow beaches adjacent to roads resulting in collisions with vehicles, erosion causing egg exposure inter alia). Given that the length of the coastline surveyed was affected by the number of turtles encountered on a given night, the survey effort was not consistent, and the percentage of nesting activities that occurred on these beaches where the female was actually observed while nesting, was relatively low compared to the index beach. However, since day patrols (05:00 to 17:00 h) covered beaches that were not patrolled the night before, all highdensity nesting beaches were visited at least once in every $24 \mathrm{~h}$ period and nest counts were reliable.

Additional beaches where low levels of nesting were reported on the northwest, east, and southeast coasts of Barbados were patrolled opportunistically in order to record nests. Finally, the Sea Turtle Hotline continued to be monitored year round, providing additional data on nesting activity.

Data recorded. Data were collected according to a standard protocol based on internationally recognised techniques (Eckert et al. 1999). Any indication of turtle activity (i.e. tracks, sand disturbed in a way that was characteristic of nesting) was documented and the presence of eggs confirmed through careful digging by hand. Turtles that were observed on the beach were approached once egg deposition commenced. Flexible tape measures $( \pm 0.1 \mathrm{~cm})$ were used to take curved carapace length ( $\mathrm{CCL}$; notch to tip) and curved carapace width (CCW) measurements of each nesting female. A sub-sample of hawksbills nesting on the index beach was also weighed immediately after egglaying in the 2003 and 2004 nesting seasons, using a Salter balance $( \pm 0.5 \mathrm{~kg})$ suspended from a bamboo pole with ropes. Turtles not previously tagged were fitted with 2 Inconel tags (Size 681, National Band and Tag Company), 1 in each front flipper, during the last stages of egg deposition or upon the commencement of covering, using established techniques (Eckert \& Beggs 2006). Before tags were applied, the proximal pads on both front flippers were checked for signs of tag scars, appearing either as a hole or as a nodule of scar tissue (Limpus 1992). If the turtle had 1 tag scar and 1 previously applied tag, a new tag was applied; if it had 2 tag scars, 2 new tags were applied. A total of 1179 nesting turtles were flipper tagged over the years 1997 to 2004.

Female turtles were assigned 1 of 3 classifications when first observed on the beach within a season. Primary turtles were females that were not carrying tags and did not have tag scars, i.e. the majority of turtles encountered in the early years of the programme. While Primary females did not have tags or scars, this did not exclude the possibility that they were either missed in a previous season(s), were on very long remigration intervals or had bred in other locations before nesting on Barbados. Given that a female tagged while nesting on Barbados has never been observed nesting outside of Barbados, the latter explanation was unlikely. Inter-season Remigrants were females carrying at least 1 tag from a previous breeding season. Tag-Scar Remigrants were females that had tag scars from a previous nesting season, but which no longer carried tags. To further investigate the breeding condition of some of the Primary females on 
the index beach, laparoscopic examination of the gonads of 4 animals was conducted in 2004 (by J. Miller) following standard protocols (Limpus \& Reed 1985).

Data analysis. Although data on nesting activity were collected over a 13 yr period (1992 to 2004), most of the statistical analyses focused on the data collected on the index beach or on the high-density nesting beaches between 1997 and 2004. Given the difference in survey effort, many more nests could be attributed to nesting females identified on the index beach than on the other high-density nesting beaches. Therefore, in order to compare the effects of survey effort on estimates of clutch frequency, data collected on the index beach only were compared to data collected on other high-density nesting beaches. The inter-nesting interval was calculated as the number of days between egg-laying and a subsequent nesting emergence (successful

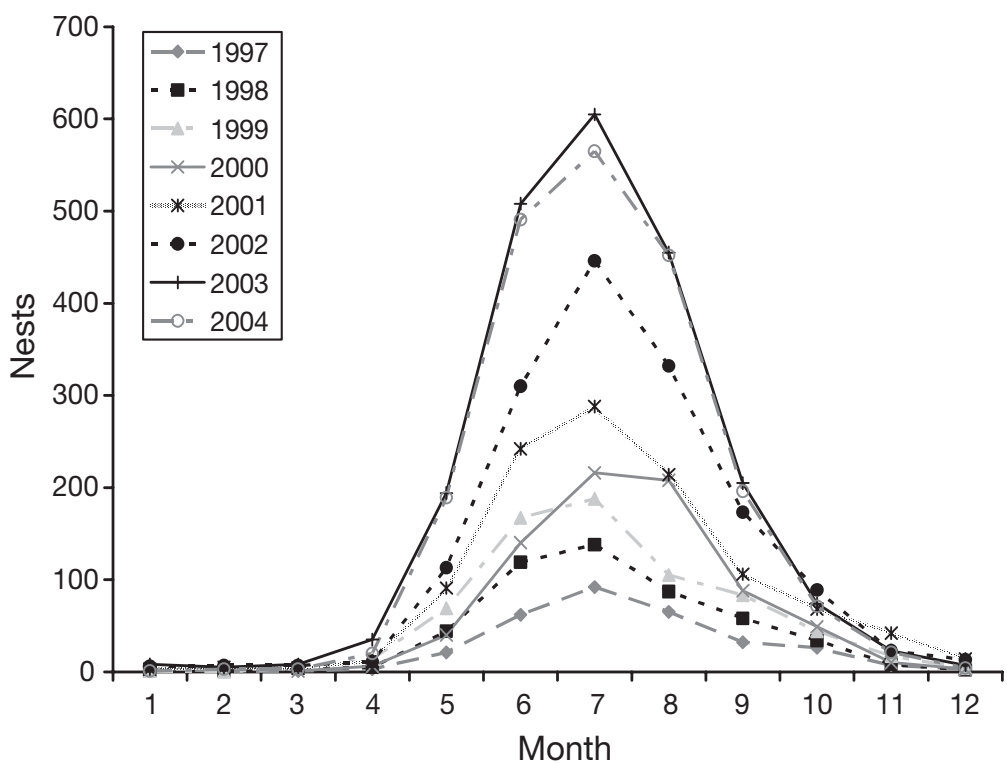

Fig. 2. Eretmochelys imbricata. Number of hawksbill nests documented each month on Barbados (1997 to 2004) or not), assuming that a female emerged onto a beach to deposit eggs, and included all females witnessed on patrolled beaches between 1997 and 2004 .

Data were analyzed using Microsoft Excel and SPSS Graduate Pack 13.0. All data met normality requirements or were transformed prior to analysis as appropriate (Zar 1999). Unless otherwise stated, the statistical significance level was set at $p<0.05$. Means are reported with standard deviations $( \pm \mathrm{SD})$.

\section{RESULTS}

Hawksbills nested year round, in all years between 1997 and 2004, with a strong peak in the months of June to August and very low levels of nesting from December to April (Fig. 2). Nesting was typically nocturnal, with $75 \%$ of all nesting occurring between 20:00 and 01:00 h, and only 32 recorded incidences of diurnal nesting over the $8 \mathrm{yr}$ period.

\section{Female morphometrics}

The mean CCL of all nesting turtles measured between 1997 and 2004 was $89.7 \mathrm{~cm}(\mathrm{SD}=3.74 ; \mathrm{n}=$ 1310 ; range $=76.2$ to $102.4 \mathrm{~cm}$; Fig. 3) and the mean mass of nesting females (index beach in 2003 and 2004 only) was $68.2 \mathrm{~kg}(\mathrm{SD}=8.8 \mathrm{~kg} ; \mathrm{n}=68$; range $=44.0$ to $92.0 \mathrm{~kg}$; Fig. 4). The CCL measurements of Primary (89.3 cm, n = 709) and Remigrant $(90.3 \mathrm{~cm}, \mathrm{n}=565)$ females were compared to see if there was a difference in size between these categories. Although significant ( $z$-test; $z=-4.96, \mathrm{p}<0.001$ ), the difference of only $1.0 \mathrm{~cm}$ between the mean CCL measurements and the overlapping SDs meant that the 2 groups could not be reliably differentiated on length measurements alone. Interestingly, however, the mean mass of females on the index beach that were identified as Primary turtles (64.9 $\mathrm{kg}, \mathrm{n}=43$ ) was significantly less than the mean mass of Remigrant turtles $(73.9 \mathrm{~kg}, \mathrm{n}=25 ; t(66)=4.65$, $\mathrm{p}<0.001$ ), and there was a significant positive correlation between CCL and mass, both for Primary turtles $\left(\mathrm{R}^{2}=0.45 ; \mathrm{r}=0.67, \mathrm{p}<0.001\right)$ and for Remigrants $\left(\mathrm{R}^{2}=\right.$ 0.66; $\mathrm{r}=0.81, \mathrm{p}<0.001$; Fig. 5).

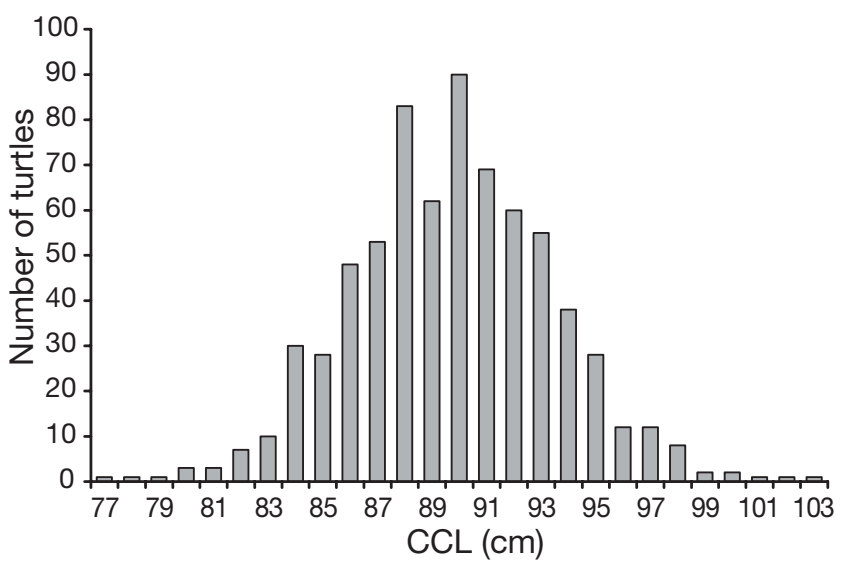

Fig. 3. Eretmochelys imbricata. Distribution of curved carapace length (CCL) measurements of hawksbills nesting on Barbados (1997 to 2004) 


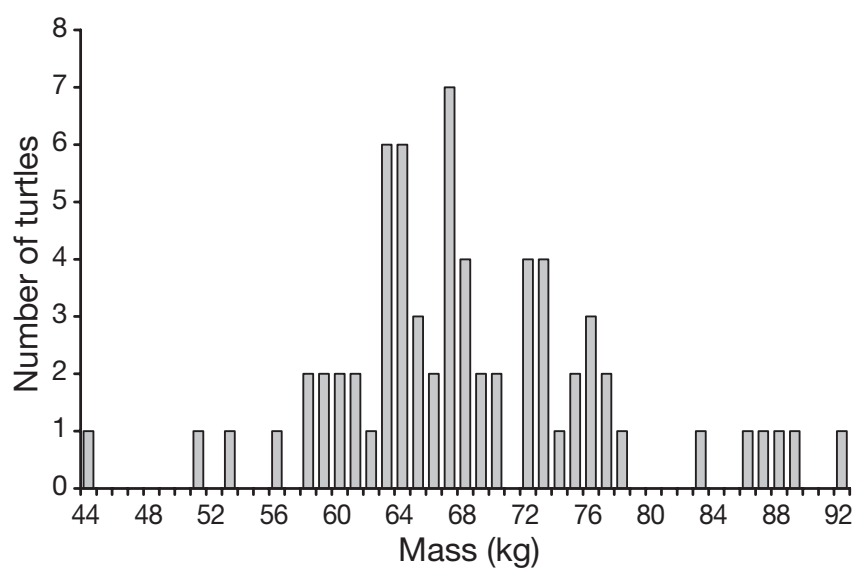

Fig. 4. Eretmochelys imbricata. Distribution of mass of hawksbills nesting on the index beach on Barbados (2003 to 2004)

\section{Remigration interval}

Overall, the average remigration interval for hawksbills in Barbados was $2.5 \pm 0.8$ yr $(\mathrm{n}=441)$. Over $55 \%$ of all individuals ( $\mathrm{n}=174$ out of 316 females recorded in 2 or more nesting seasons) were documented solely on 2 yr remigration intervals (Table 1). A further 71 females were recorded only on 3 yr intervals. Only 2 individuals were documented nesting annually, and only on the 2 occasions. Remigration intervals of individual females often varied between seasons (Table 1). The longest remigration interval recorded was 6 yr $(n=3)$.

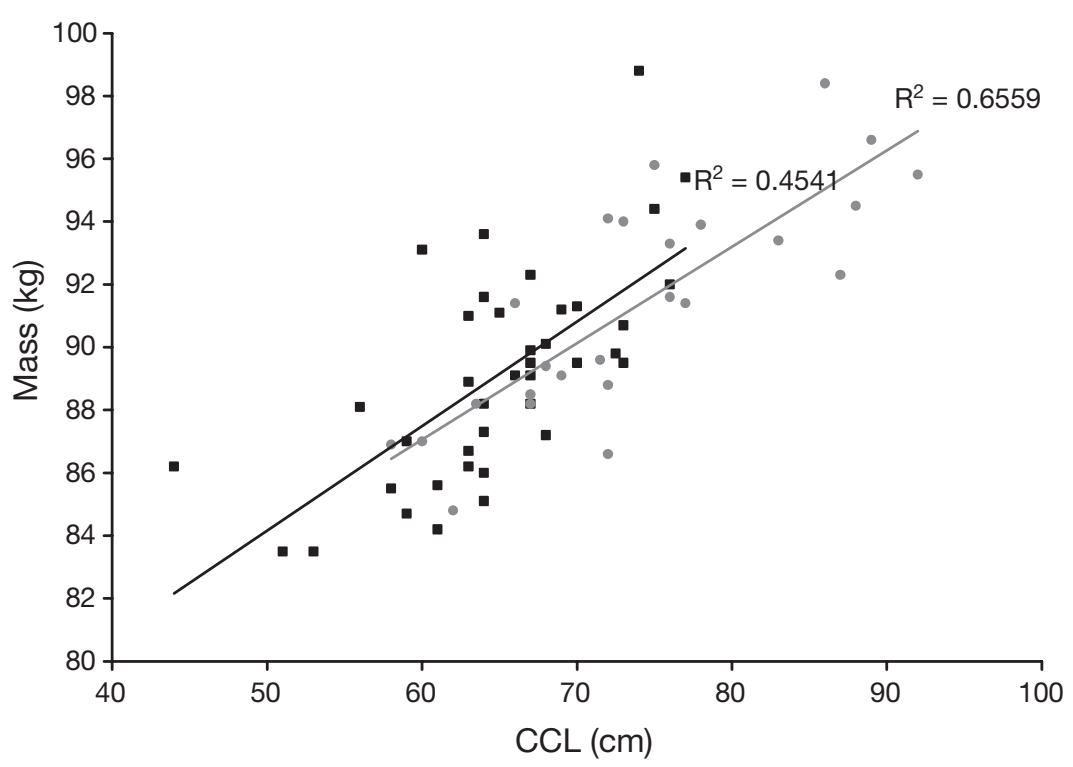

Fig. 5. Eretmochelys imbricata. Correlation between curved carapace length (CCL) and mass, shown separately for Primary $\left(\boldsymbol{~}_{i} \mathrm{n}=39\right)$ and Remigrant $(\bullet ; \mathrm{n}=25)$ females (2003 to 2004) (see 'Materials and methods; Data recorded' for further details)
The proportion of Remigrant turtles encountered on the index beach increased over the $8 \mathrm{yr}$ period from $5 \%$ in 1997 to a high of $51.5 \%$ in 2002, but had declined to 43.4 and $45.6 \%$ in 2003 and 2004, respectively.

\section{Clutch frequency and inter-nesting interval}

Two measures of average clutch frequencies were calculated: (1) observed clutch frequency (OCF), the number of clutches observed being laid by a female in a season (Frazer \& Richardson 1985, Johnson \& Ehrhart 1996, Broderick et al. 2002); and (2) estimated clutch frequency (ECF), the number of clutches estimated to have been laid by a female in a season, i.e. including nests that were not witnessed (Frazer \& Richardson 1985, Johnson \& Ehrhart 1996, Broderick et al. 2002) (Table 2). The inter-nesting interval, based on observed nests by tagged females, was calculated as $14.9 \pm 1.3 \mathrm{~d}$ (range $=9$ to $21 ; \mathrm{n}=942$ ). Therefore, turtles that were witnessed with inter-nesting intervals of $22 \mathrm{~d}$ or longer were considered to have nested undetected within this period and the 'missed' nest(s) was/were included in the calculation of ECF (see also Alvarado \& Murphy 1999). To ensure that the first and last nests laid by a female were counted, females included in the estimates of clutch frequency were those that initiated nesting after the middle of May and completed their nesting by the end of September, when intensive beach monitoring ceased. Females that were observed nesting only once in the season were eliminated from the estimation of clutch frequency, as it was more likely that these were females that laid their other clutches on adjacent and less frequently patrolled beaches. This was based on the observation that $17 \%$ of females observed to nest at least once on the index beach were also seen nesting on other beaches within the same season. To have included single clutches in the calculation would therefore have lowered the mean clutch frequency erroneously.

Given that the percentage of nests where the responsible females had been identified was greatest in 2003 and 2004 on the index beach (93 and 90.2\% respectively), these 2 years were combined to provide an average ECF of 4.1 nests per female (Table 2). In order to investigate whether there was a difference in clutch frequencies between Primary females and those identified as 
Table 1. Eretmochelys imbricata. Distribution of remigration intervals (in years) for hawksbill turtles nesting on Barbados in $>2$ nesting seasons. Females seen in $\geq 3$ breeding seasons are indicated by their first documented remigration interval; +: their second remigration interval, etc.

\begin{tabular}{|cc|}
\hline Remigration intervals & No. of females \\
\hline 2 & 114 \\
3 & 65 \\
4 & 30 \\
5 & 7 \\
6 & 3 \\
$2+2$ & 37 \\
$2+3$ & 7 \\
$2+4$ & 2 \\
$3+1$ & 1 \\
$3+2$ & 11 \\
$3+3$ & 6 \\
$3+4$ & 1 \\
$4+2$ & 4 \\
$5+2$ & 1 \\
$1+2+2$ & 1 \\
$2+2+2$ & 23 \\
$2+2+3$ & 2 \\
$2+3+2$ & 1 \\
\hline
\end{tabular}

Remigrant females, clutch frequencies were compared between the 2 groups in the same 2 years. Primary turtles $(\mathrm{n}=107$ ) laid significantly fewer clutches (average of $3.6 \pm 1.4$ clutches per season) than Remigrant turtles ( $\mathrm{n}=66$; average of $4.1 \pm 1.4$ clutches per season; $z$-test; $z=-2.23, \mathrm{p}<0.05)$.

\section{Laparoscopic examinations}

Two of the 4 untagged post-nesting females examined were determined to have bred in at least one previous season. Therefore, not all Primary females could be definitively confirmed as new recruits to the Barbados nesting population, despite a lack of tags or tag scars.

\section{Trend in abundance and population estimate}

The number of nests documented on the Needham's Point index beach increased markedly between 1992 and 2004 (Table 3). The method used to assess nest numbers changed in 1997 from early morning surveys to all night patrols, coinciding with a 2-fold increase in nest number compared to that reported for 1996. Although effort was consistent in the years pre-1997 and again in the years post-1997, it is possible that some nests may have been missed in the years when counts were made during early morning surveys, due to tracks being washed over. However, the width of the index beach along most of its length suggests that this would have occurred fairly infrequently. From 1997 onwards, nest counts were made during the night and missed nests would have been very rare.

Table 3. Eretmochelys imbricata. Number of nests documented on the index beach (Needham's Point) during the period June to September over the years 1992 to 2004. Method 1: early morning nest counts; Method 2: all night patrols

\begin{tabular}{|cc|}
\hline Year & Nests \\
\hline Method 1 & \\
1992 & 41 \\
1993 & 38 \\
1994 & 22 \\
1995 & 55 \\
1996 & 46 \\
Method 2 & \\
1997 & 89 \\
1998 & 95 \\
1999 & 120 \\
2000 & 127 \\
2001 & 193 \\
2002 & 234 \\
2003 & 327 \\
2004 & 328 \\
\hline
\end{tabular}

Table 2. Eretmochelys imbricata. Observed clutch frequency (OCF) and estimated clutch frequency (ECF) for those turtles utilizing the index beach (Needham's Point) for nesting, and for those turtles nesting on high density nesting beaches surveyed less intensively

\begin{tabular}{|c|c|c|c|c|c|c|}
\hline Year & $\begin{array}{l}\text { Index beach } \\
\text { OCF }\end{array}$ & $\mathrm{ECF}$ & $\mathrm{N}$ & $\begin{array}{c}\text { High density nesting } \\
\text { beaches OCF }\end{array}$ & $\mathrm{ECF}$ & $\mathrm{N}$ \\
\hline 1997 & $2.0 \pm 0.0$ & $2.7 \pm 1.0$ & 7 & - & - & - \\
\hline 1998 & $3.2 \pm 1.1$ & $3.8 \pm 1.5$ & 17 & $2.4 \pm 0.6$ & $2.8 \pm 0.8$ & 25 \\
\hline 1999 & $2.8 \pm 0.6$ & $3.5 \pm 1.4$ & 17 & $2.5 \pm 0.7$ & $2.9 \pm 0.9$ & 30 \\
\hline 2000 & $2.5 \pm 0.5$ & $3.1 \pm 1.2$ & 9 & $2.5 \pm 0.8$ & $3.3 \pm 1.1$ & 26 \\
\hline 2001 & $2.4 \pm 0.7$ & $3.3 \pm 1.3$ & 27 & $2.3 \pm 0.5$ & $3.2 \pm 1.1$ & 33 \\
\hline 2002 & $3.5 \pm 1.2$ & $4.2 \pm 1.5$ & 33 & $2.4 \pm 0.8$ & $3.5 \pm 1.3$ & 79 \\
\hline 2003 & $3.9 \pm 1.3$ & $4.0 \pm 1.2$ & 64 & $2.5 \pm 0.8$ & $3.5 \pm 1.2$ & 121 \\
\hline 2004 & $3.7 \pm 0.6$ & $3.9 \pm 0.8$ & 70 & $2.4 \pm 0.6$ & $3.2 \pm 1.1$ & 76 \\
\hline 2003-2004 & $3.8 \pm 1.2$ & $4.1 \pm 1.1$ & 134 & $2.5 \pm 0.7$ & $3.4 \pm 1.2$ & 197 \\
\hline
\end{tabular}


In order to estimate annual nesting cohort sizes, the total number of nests documented on the index beach and islandwide within a season was divided by the ECF of 4.1 clutches per female. The estimated numbers of females nesting per year are shown in Table 4. The current estimated total population size of adult females using Barbados as a nesting ground was calculated using a mean annual cohort size calculated from the years 2003 and 2004. The mean number of females estimated to nest annually on the index beach was 94 and on all beaches islandwide (including the index beach) was 506. The accuracy of the estimated annual cohort sizes in 2003 and 2004 in Table 4 was supported by an annual nest count of over 2000 nests in each of these 2 years. The cohort estimates were then multiplied by the mean remigration interval for the population, i.e. $2.47 \mathrm{yr}$, to give an estimate of 232 females nesting on the index beach alone, and a total of 1250 females nesting on Barbados as a whole.

\section{DISCUSSION}

The nesting beach monitoring programme on Barbados has provided the longest time series of data on the reproductive female segment of a hawksbill sea turtle population in the southeastern Caribbean. The data were collected over an important time period (1992 to 2004) when national conservation efforts were underway to recover the severely depleted population of nesting hawksbills in Barbados. These in-country efforts were no doubt supplemented during this period by reductions in hawksbill catches within the region (e.g. Cuba; Carillo et al. 1999, Mortimer et al. 2007) and by temporary moratoria on sea turtle catches (e.g.
St. Lucia) in areas where turtles tagged in Barbados are known to forage (Krueger et al. 2006). The data suggest that the decline in nesting has been reversed on Barbados and a dramatic increase in nesting has been recorded over the course of little more than a decade. The estimated nesting population size of 1250 suggests that Barbados is the second largest rookery (after Mexico) in the wider Caribbean, and given its up-current position on the eastern edge of the Caribbean Sea, likely a very significant contributor to foraging grounds throughout the region.

Hawksbill turtles migrate from their foraging grounds to nest on Barbados on average every $2.5 \mathrm{yr}$, with 2 yr being the most common interval and 6 yr the longest. It is possible that a small percentage of turtles exhibiting remigration intervals longer than $3 \mathrm{yr}$ may have nested between those years and were missed by patrols. However, since females need only be observed once during a nesting season to confirm their presence in a given year, this seems unlikely. For both Jumby Bay, Antigua, and Buck Island, St. Croix, it was reported that 2 yr remigrations were most common, followed by 3 yr and then 4 yr remigrations (Hillis 1994, Richardson et al. 1999). Mortimer \& Bresson (1999) found that 2 and 3 yr intervals were most common in Seychelles hawksbills in the Indian Ocean, but that intervals of up to $6 \mathrm{yr}$ were also not uncommon. A 5 yr study of hawksbills nesting at Milman Island, Australia, concluded that turtles nested on an average remigration interval of 3.4 yr (Dobbs et al. 1999), but a 10 yr study documented a longer average remigration interval of $5 \mathrm{yr}$ (J. Miller pers. comm.). As was found in Barbados, longer remigration intervals of 5 and $6 \mathrm{yr}$ were only documented in very small numbers at Jumby Bay, despite the latter data being derived from an 11 yr saturation tagging study (Richardson et al. 1999). This may suggest that longer remigration intervals are not as common in Caribbean hawksbill populations as they are in the Indian or southern Pacific Oceans.

Remigration intervals of individual females nesting on Barbados did exhibit variation, suggesting that there are considerable environmental influences on nesting periodicity. For instance, variation in remigration intervals may be linked to distance between foraging grounds and nesting beaches and/or the body condition of an individual in any given year (see Hamann et al. 2003). The availability of food and the ability to increase energy stores in non-breeding years, especially when long migrations are 
involved, is likely to be vital in determining if the following year is to be a breeding year or not. Therefore, the quality of the foraging grounds and the oceanographic conditions which affect food availability (Dobbs et al. 1999, Broderick et al. 2001) are likely to have a direct impact on hawksbill remigration intervals.

The average CCL and average mass for breeding females on Barbados were similar to those reported for females nesting in Antigua (Richardson et al. 1999) and St. Croix (Hillis 1994), but were larger than reported for adult females caught at sea in the Cuban fishery (typically 76 to $80 \mathrm{~cm}$ straight carapace length, Moncada et al. 1999). In Barbados, Primary and Remigrant females differed in both length and mass, with the former tending to be smaller in size and lighter in mass than the latter. This result must, however, be viewed with caution, given that 2 of the 4 untagged females that were examined laparoscopically in 2004, i.e. in the later years of our study, were not found to be first time breeders (see also Mortimer \& Bresson 1999).

The mean clutch frequency of hawksbills is reported to vary widely in the Caribbean (IUCN 2002), from a high of 4.5 nests per season in Antigua (Richardson et al. 1999) to a low of 2.1 per season in Mexico (Garduño-Andrade et al. 1999). The average clutch frequency per season for hawksbills in Barbados was 4.1. The OCF and the ECF on the index beach varied over the 8 yr period, but were consistently higher than those derived from data collected on the high-density nesting beaches (Table 2), showing clearly how clutch frequency estimates are underestimated when survey effort is reduced. Therefore, some of the variation in clutch frequency estimates seen in the region may be best explained by the method of data collection. For instance, the reported 4.5 nests per female per season in Antigua (Richardson et al. 1999) resulted from data collected on a small beach which was studied intensively for a longer period of the nesting season than our study, while the estimate of 2.1 by Garduño-Andrade et al. (1999) was obtained from twice nightly patrols of long nesting beaches. Despite efforts to overcome methodological and logistical challenges in achieving good beach coverage over the 8 yr tagging study on Barbados, the overall estimated clutch frequency of 4.1 is still likely to be an underestimate of actual clutch frequency, since the possibility exists that the first clutch or last clutch could have been missed for some individual females.

It has been suggested that new recruits may lay fewer clutches (Mortimer \& Bresson 1999). If so, recovering populations with high levels of recruitment may exhibit lower average clutch frequencies. Although reproductive status can only reliably be ascertained by laparoscopic techniques, Primary females were found to lay fewer clutches than Remigrant females in the present study. Whether the difference in clutch frequency is attributable to differences in female maturation or due to behavioural differences in nest site selection, leading to newly maturing females being less faithful to particular beaches and hence less likely to have all their clutches recorded, is currently under investigation (see also Mortimer \& Bresson 1999).

The degree to which the increase in number of females seen on Barbados was the result of higher levels of recruitment as opposed to higher levels of survival of Remigrant females is of significant interest in terms of guiding conservation and management. Recruitment can typically be assessed by observing the changes in the ratio of remigrant to untagged turtles over years of monitoring (e.g. Richardson et al. 1999, 2006). With an intensive saturation tagging programme, all existing breeding females should be tagged after a period of years. Thereafter, untagged turtles can be assumed to be new recruits or perhaps wandering turtles with an unknown prior history of nesting (Richardson et al. 1999). Despite our best efforts in Barbados, not all breeding females could be witnessed and tagged on the index beach in any given year, making it impossible to determine conclusively from exterior examination whether an untagged turtle was indeed a first-time nester or an untagged Remigrant that had been missed in an earlier nesting season. Notwithstanding these constraints, the proportion of Remigrant turtles encountered on the index beach increased over the $8 \mathrm{yr}$ tagging study to a high of $51.5 \%$ in 2002 , but levelled off at 40 to $45 \%$, suggesting that relatively more Primary turtles than Remigrants are making up the population in recent years (see also Richardson et al. 2006).

If higher levels of recruitment are primarily responsible for the increase in numbers of nesting hawksbills on Barbados, there may be several contributing factors. Heavy fishing mortality in Barbados in the middle of the last century had declined by the 1980s, presumably largely due to a population collapse that made fishing unprofitable. The national moratorium enacted in 1998 provided added protection, particularly to the juvenile and sub-adult size classes around Barbados, most of which had not previously been protected by national legislation. Given that harvests on foraging grounds are likely to be most detrimental to nearby nesting populations (Bowen et al. 2007), the reduction in fishing pressure around Barbados may have increased the numbers of juveniles surviving to breeding age. As a result of reduced incentives to capture hawksbills when the international shell trade ceased, combined with the initiation of beach patrols by the BSTP, which reduced the opportunities to illegally harvest nesting females, survival of nesting females on 
Barbados beaches likely increased over the 1990s. The widespread movement of Barbados-tagged hawksbills in the region (e.g. Horrocks et al. 2001) suggests that conservation and management initiatives in other range states have also contributed significantly to the increases seen on Barbados. The large decrease in capture of turtles from 5000 to 500 individuals $\mathrm{yr}^{-1}$ in the Cuban nearshore turtle fishery (Carrillo et al. 1999), and the moratorium on turtle capture in neighbouring St. Lucia between 1996 and 2004, are likely to have resulted in higher recruitment and survival probabilities for Barbados nesting females. Tag returns from 7 different countries in the region indicate that Barbados hawksbills utilize many foraging grounds. Management of sea turtle fisheries and changes in fishing pressure elsewhere in the Caribbean therefore have the potential to significantly affect hawksbill population numbers, and to promote or to undermine national conservation efforts in Barbados.

Acknowledgements. This study was conducted with research permits granted by the Fisheries Division of the Ministry of Agriculture and Rural Development, Government of Barbados. We gratefully acknowledge William Bertalan, Darren Browne, Karen Eckert, Renata Goodridge, Asanchia Harewood, Wayne Hunte, Kirtis Luke, Jeff Miller, Hazel Oxenford, Christopher Parker, Lotus Vermeer, Stephen Willoughby, the many BSTP interns and Earthwatch Institute volunteers who patrolled the nesting beaches over the years, and the thousands of Barbadians and visitors who have called the Sea Turtle Hotline. Financial and in-kind support from the University of the West Indies, Earthwatch Institute and its Volunteers, Peter Moores Barbados Trust, UNDP/SGP, Ocean Fund of Royal Caribbean Cruises, the British High Commission (Barbados), the Australian High Commission (Trinidad \& Tobago), the Barbados Tourism Development Corporation, Coconut Court Beach Resort, Divi Southwinds and Divi Heritage, Jefferson Community College, and WIDECAST is gratefully acknowledged.

\section{LITERATURE CITED}

Alvarado J, Murphy TM (1999) Nesting periodicity and internesting behaviour. In: Eckert KL, Bjorndal KA, Abreu-Grobois A, Donnelly M (eds) Research and management techniques for the conservation of sea turtles. IUCN/SSC Marine Turtle Specialist Group Publication No. 4, Washington, DC, p 115-118

Baillie J, Groombridge B (1996) IUCN Red List of Threatened Animals. IUCN, Gland

Bass AL, Good DA, Bjorndal KA, Richardson JI, Hillis ZM, Horrocks JA (1996) Testing models of female reproductive migratory behaviour and population structure in the Caribbean hawksbill turtle, Eretmochelys imbricata, with mtDNA sequences. Mol Ecol 5:321-328

Bjorndal KA, Carr A (1989) Variation in clutch size and egg size in the green turtle nesting population at Tortuguero, Costa Rica. Herpetologica 45:181-189

Bowen BW, Grant WS, Hillis-Starr Z, Shaver DJ, Bjorndal KA, Bolten AB, Bass AL (2007) Mixed stock analysis reveals the migrations of juvenile hawksbills, Eretmochelys imbri- cata, in the Caribbean Sea. Mol Ecol 16:49-60

Broderick AC, Glen F, Godley BJ, Hays GC (2001) Trophic status drives inter-annual variability in nesting numbers of marine turtles. Proc R Soc Lond Ser B 268:1481-1487

Broderick AC, Glen F, Godley BJ, Hays GC (2002) Estimating the size of nesting populations of green and loggerhead turtles in the Mediterranean. Oryx 36:227-236

Carillo EC, Webb JW, Manolis SC (1999) Hawksbill turtles (Eretmochelys imbricata), in Cuba: an assessment of the historical harvest and its impacts. Chelonian Conserv Biol 3:264-280

Dobbs KA, Miller JD, Limpus CJ, Landry AM (1999) Hawksbill turtle, Eretmochelys imbricata, nesting at Milman Island, Northern Great Barrier Reef, Australia. Chelonian Conserv Biol 3:344-361

Eckert KL, Beggs J (2006) Marine turtle tagging: a manual of recommended practices. WIDECAST Technical Report No. 2 (Revised edn), Beaufort, NC

Eckert KL, Bjorndal KA, Abreu-Grobois A, Donnelly M (1999) (eds) Research and management techniques for the conservation of sea turtles. IUCN/SSC Marine Turtle Specialist Group Publication No. 4, Washington, DC

Frazer NB (1984) A model for assessing mean age-specific fecundity in sea turtle populations. Herpetologica 40: 281-291

Frazer NB, Richardson JI (1985) Annual variation in clutch size and frequency for loggerhead turtles, Caretta caretta, nesting at Little Cumberland Island, Georgia, USA. Herpetologica 41:246-251

Garduño-Andrade M, Guzman V, Miranda E, BriseñoDueñas R, Abreu-Grobois FA (1999) Increases in hawksbill turtle (Eretmochelys imbricata) nesting in the Yucatan Peninsula, Mexico, 1977-1996: data in support of successful conservation. Chelonian Conserv Biol 3:286-295

Hamann M, Limpus CJ, Owens DW (2003) Reproductive cycles of males and females. In: Lutz PL, Musick JA, Wyneken J (eds) The biology of sea turtles, Vol II. CRC Press, Boca Raton, FL, p 135-161

Hillis ZM (1994) The first five years at Buck Island Reef Monument - the hawksbill story. In: Schroeder BA, Witherington BE (Compilers) Proceedings of the Thirteenth Annual Symposium on Sea Turtle Biology and Conservation. NOAA Tech Memo NMFS-SEFSC-341, Miami, FL, p 242-245

Horrocks JA (1992) WIDECAST sea turtle recovery action plan for Barbados. CEP Technical Report No. 12. UNEP Caribbean Environment Programme, Kingston

Horrocks JA, Vermeer LA, Krueger BH, Coyne M, Schroeder BA, Balazs GH (2001) Migration routes and destination characteristics of post-nesting hawksbill turtles satellitetracked from Barbados, West Indies. Chelonian Conserv Biol 4:107-114

IUCN (2002) Hawksbill turtles in the Caribbean region: basic biological characteristics and population status. CITES Wider Caribbean Range State Hawksbill Dialogue.

Johnson SA, Ehrhart LM (1996) Reproductive ecology of the Florida green turtle: clutch frequency. J Herpetol 30: 407-410

Krueger BK, Horrocks JA, Beggs JA (2006) International movements of adult female and juvenile hawksbill turtles, Eretmochelys imbricata, from Barbados, West Indies. In: Pilcher NJ (Compiler) Proceedings of the 23rd Annual Symposium on Sea Turtle Biology and Conservation, NOAA Tech Memo NMFS-SEFSC-536

Limpus CJ (1992) The hawksbill turtle, Eretmochelys imbricata, in Queensland: population structure within a southern Great Barrier Reef feeding ground. Wildl Res 19:489-506 
Limpus CJ, Reed PC (1985) The green turtle Chelonia mydas in Queensland: a preliminary description of the population structure in a coral reef feeding ground. In: Grigg G, Shine R, Ehmann H (eds) Biology of Australian frogs and reptiles. Surrey Beatty \& Sons, Chipping Norton (NSW), p 47-52

Meylan AB (1999) Status of the hawksbill turtle, Eretmochelys imbricata, in the Caribbean region. Chelonian Conserv Biol 3:177-184

Moncada F, Carillo E Saenz A, Nodarse G (1999) Reproduction and nesting of the hawksbill turtle, Eretmochelys imbricata, in the Cuban Archipelago. Chelonian Conserv Biol 3:257-263

Mortimer JA, Bresson R (1999) Temporal distribution and periodicity in hawksbill turtles (Eretmochelys imbricata) nesting at Cousin Island, Republic of Seychelles, 1971-1997. Chelonian Conserv Biol 3:318-325

Mortimer JA, Meylan PA, Donnelly M (2007) Whose turtles are they, anyway? Mol Ecol 16:17-18

Richardson JI, Bell R, Richardson TH (1999) Population ecol-

Editorial responsibility: Brendan Godley (Editor-in-Chief),

University of Exeter, Cornwall Campus, UK ogy and demographic implications drawn from an 11-year study of nesting hawksbill turtles, Eretmochelys imbricata, at Jumby Bay, Long Island, Antigua, West Indies. Chelonian Conserv Biol 3:244-250

Richardson JI, Hall DB, Mason PA, Andrews KM, Bjorkland R, Cai Y, Bell R (2006) Eighteen years of saturation tagging data reveal a significant increase in nesting hawksbill sea turtles (Eretmochelys imbricata) on Long Island, Antigua. Anim Conserv 9:302-307

Schroeder B, Murphy S (1999) Population surveys (ground and aerial) on nesting beaches. In: Eckert KL, Bjorndal KA, Abreu-Grobois A, Donnelly M (eds) Research and management techniques for the conservation of sea turtles. IUCN/SSC Marine Turtle Specialist Group Publication No. 4, Washington, DC, p 45-53

Witzell WN (1983) Synopsis of biological data on the hawksbill sea turtle, Eretmochelys imbricata (Linnaeus, 1766). FAO Fish Synopsis No. 137, FAO, Rome

Zar JH (1999) Biostatistical analysis, 4th edn. Prentice Hall, Englewood Cliffs, NJ

Submitted: December 15, 2006; Accepted: July 4, 2007

Proofs received from author(s): July 29, 2007 